BOMBAY HUSTLE

Film and Culture 
FILM AND CULTURE

A series of Columbia University Press Edited by John Belton

For a complete list of titles, see page 421 


\section{Bombay Hustle}

Making Movies in a Colonial City

\section{Debashree Mukherjee}


Columbia University Press

Publishers Since 1893

New York Chichester, West Sussex

cup.columbia.edu

Copyright (๑) 2020 Columbia University Press

All rights reserved

Library of Congress Cataloging-in-Publication Data

Names: Mukherjee, Debashree (Film historian), author.

Title: Bombay hustle : making movies in a colonial city / Debashree Mukherjee.

Description: New York : Columbia University Press, [2020] | Includes bibliographical references and index.

Identifiers: LCCN 2020004387 (print) | LCCN 2020004388 (ebook) | ISBN 9780231196147 (cloth) | ISBN 9780231196154 (paperback) | ISBN 9780231551670 (ebook)

Subjects: LCSH: Motion picture industry-India-Mumbai-History-2oth century.

Classification: LCC PN1993.5.I8 M844 2020 (print) | LCC PN1993.5.I8 (ebook) |

DDC 791.430954/792-dc23

LC record available at https://lccn.loc.gov/2020004387

LC ebook record available at https://lccn.loc.gov/2020004388

Columbia University Press books are printed on permanent and durable acid-free paper.

Printed in the United States of America

Cover design: Milenda Nan Ok Lee

Cover image: Production still from the sets of Achhut Kanya (Untouchable Girl, Franz Osten, 1936). Image courtesy of the Josef Wirsching Archive and the Alkazi Collection of Photography. 
For Ma, Baba, and Enid 
